\title{
Evaluating the perceptions of ESL students towards collaborative learning on improving their writing skills
}

Emmanuel Mensah Bonsu ( $\nabla$ ebonsu@stu.ucc.edu.gh )

University of Cape Coast https://orcid.org/0000-0002-7867-8204

\section{Research Article}

Keywords: perceptions, collaborative learning, writing skills, language education, ESL

Posted Date: February 15th, 2022

DOI: https://doi.org/10.21203/rs.3.rs-1352074/v1

License: (c) (1) This work is licensed under a Creative Commons Attribution 4.0 International License.

Read Full License 


\section{Abstract}

Developing the writing skills of ESL students have been the focus of language education scholars for the past three decades. This relates to the importance writing has accrued among the other language skills. Collaborative learning has been debated as an approach to improve the writing skills of students. The study investigated (a) the perceptions of ESL students towards collaborative learning, and (ii) the perceived effect of collaborative learning on the writing skills of ESL students. Thirty participants from an English language course were randomly sampled. The quantitative analyses and discussion show that students have a positive perception towards collaborative learning which influences their interest to be actively and frequently engaged in it. Peer feedback was essential to improving the writing skills and developing general language skills through collaborative learning. The study reports an overall effect of collaborative learning improving the writing skills of learners. After providing the limitations of the study, implications and recommendations are stated for further research.

\section{Introduction}

Learning is a lifelong activity. The learning of a second language such as the English language has proven to be a difficult task for most students in several contexts. Veramuthu and Shah (2020) opine that writing is "pigeon-holed as an intricate task" (p. 55). Ivanic (1998) holds a view that writing should portray the identity of the student. That is, most second language learners find writing difficult when they are not comfortable with portraying themselves in the content of their writing. Weigle (2007) acknowledges the relevance of writing as a skill. Huy (2015) points out that writing is an important skill in the English language as it translates itself from the academic field to corporate settings. While there is a large scholarship that recognizes the importance of writing, most English as Second Language (hereinafter, ESL) learners are not aware of this relevance and still encounter difficulties in writing. Following this challenge, several strategies have been devised to improve the writing skills of ESL learners: through oral feedback (Schuldt, 2019; Solhi \& Eginli, 2020), peer feedback (Huisman, Saab, Van Driel, \& Van Den Broek, 2018; Fan \& Xu, 2020), written feedback (Bonsu, 2021; Hyland \& Hyland, 2019), computer-mediated feedback (AbuSeileek \& Abualsha'r, 2014; Sauro, 2009), and games (Kheryadi, 2017; Mazhar, 2019). While few kinds of research have recognised the role of collaborative learning to improve the writing skills of learners (Al-Besher, 2012; Mansor, 2007), they are constrained to online interactions (Alghasab, Hardman, \& Handley, 2019; Qing-quan, 2009).

Generally, collaborative learning has evolved as an essential concept in education (Al-Besher, 2012; Kohonen \& Bedley, 1992) to be encapsulated as an activity in improving English language skills in English as Foreign Language (hereinafter, EFL) and ESL contexts (Khan \& Mansoor, 2020). Collaborative learning is conceptualized by different scholars to essentialize the objectives of learning. Umar, Adamm and Fahal (2020) explain that collaborative learning means arranging students in heterogeneously small groups to work together to achieve a common goal. Implicitly, this definition recognizes the individual differences in the competence of students. In an effort to define collaborative learning, Ibrahim, Shak, 
Mohd, Zaidi and Yasin (2015) provide a significance that it allows second language learners to rely on one another for knowledge and this makes learning more interesting and meaningful.

While the definitions holds, Ibrahim et al. (2015) advise that collaborative learning is not merely about grouping students to work together, but it involves shared meaning, negotiations and elaboration of conceptually practical knowledge (Van Boxtel, Van der Linden, \& Kanselaar, 2000). While students verbalize their understanding in the group, they can practice and improve coherent writing skills through the interaction. This assertion is supported by the claim of Wilmer (2008) that most students are underequipped to take on complex learning on their own. In this regard, the use of a collaborative learning strategy becomes necessary to facilitate the learning of such ESL learners. Al-Besher (2012) connects writing and collaborative learning to mean a heterogenous small group of ESL writers working as a team to produce and create a shared piece of writing. The result of the collaboration is the development of a piece of writing and these results catalyze to improve the writing skill of each member in the group. Rice and Huguley (1994) reveal that this is achievable when the group brainstorms, collects ideas, plans, makes an outline, revises and edits the writing. Aljamhoor (1996) extended the relevance of planning to the writing process.

The main rationale for this study emanates from the reports by scholars on the falling standards of writing skills of ESL learners after several strategies have been devised to ensure improving writing. Several theoretical perspectives such as socio-cultural theory (Dongyu, Fanyu, \& Wanyi, 2013), cognitivist theory (Flower \& Hayes, 1981;), socio-cognitivist theory (Atkinson, 2019, Barrot, 2015), genre theory (Afful, 2007; Arancón, 2013;), and interactionist theory (Bowles \& Adams, 2015;) have been originated to support the writing of ESL students. This study dwells on the effectiveness of collaborative learning to improve the writing skills of ESL learners through the perceptions of the students. This follows that the use of collaborative learning can provide opportunities for learners to improve their writing through interaction with their peers. Pham and Nguyen (2020) review the positive influence of collaborative learning through peer feedback on second language writers to enhance their self-regulatory learning and scaffold their writing. Also, some existing scholarship recommends channelling attention to improving the writing skills of students (Sukirman, 2016; Veramuthu \& Shah, 2020). Sukirman (2016) acknowledges the influence of collaborative learning to improve the writing of students through peer learning.

The study addresses two key concerns. Firstly, little research has investigated collaborative learning in the ESL context, specifically Ghana. More importantly, these studies focused on web-based and online interactions. The current study focuses on traditional collaborations. Secondly, from the extant literature, there is a debate on the suitable approach or theory to improve the writing skills of students. The present study is designed to examine the effectiveness of collaborative learning to improve writing by analysing the perceptions of students. The need to investigate the perceptions of students towards collaborative learning improving their writing stems from the assertion that perceptions are influential factors in writing skills (Bulut, 2017; Veramuthu \& Shah, 2020). This investigation can lead to renovating language learning curriculums to integrate collaborative learning as a core activity in improving learning (in this study, writing skills) of ESL students. The findings of this study can relevant to other fields of second language 
research such as feedback and language acquisition. In this regard, the study is guided by the following research questions.

i. What are the perceptions of ESL students towards collaborative learning?

ii. What is the perceived effect of collaborative learning on the writing skill of ESL students?

\section{Literature Review}

\section{Social Constructivist Theory}

Social Constructivist Theory (hereinafter, SCT) evolved as a theory from Vygotsky's Socio-cultural theory. SCT serves as a paradigm mostly adopted in language education. Yang and Wilson (2006) highlight the momentum SCT is gaining in the ESL and EFL learning contexts. Srour, Aqel and Shawish (2021) reveal that SCT distinguishes itself from the traditional perspective where teachers are seen as repositories of knowledge and active more than the learners. However, in SCT, learners are active participants who construct their knowledge and progress to be better. Vygotsky (1978) explains that the development of learners' skills through the construction of meaning by interacting with more knowledgeable peers transpire at the Zone of Proximal Development (ZPD).

SCT holds some assumptions about learning and knowledge. Within the theory, learning is a social process that does not require passive activities, but rather active engagements to facilitate development (Gredler, 1997; Kafai \& Resnick, 1996). Given that learning is a social process, knowledge is socially and culturally acquired. Meanings and understandings are created through the interaction between learners (Kukla, 2000). The emphasis on the importance of interaction and the role of peers in improving the language skills of one another is evidenced in the literature (Laal \& Ghodsi, 2012; Strijbos \& Fischer, 2007; Warmkessel \& Carothers, 1993).

From the SCT perspective, writing is a social practice developed through active interaction. Previous cognitivists (Flower \& Hayes, 1981; Hayes \& Flower, 1987) considered writing as a cognitive process; however, some tendencies have considered writing in a social constructivist sense (Hodson \& Hodson, 1998; Lantolf, 2000; Van Lier, 2000). These scholars have shifted attention from individuated activities towards sharing of mental activities amongst learners. Pea (1993) states that "the mind rarely works alone" (p. 47) and writing as a complex mental activity lends itself to the learners working together in its production.

Thus, brainstorming, collaborative problem-solving, shared planning, drafting, peer feedback, written feedback, and revisions have been recommended to be relevant in the writing process. The essence of collaboration cannot be downplayed. While the assertion is acceptable, Barnard and Campbell (2005) note that collaborative learning requires the willingness of the learners to learn from each other.

\section{Collaborative Learning}


Collaborative learning has received attention from linguists and educationists from the 1970 s to the present day. Though research on collaborative learning is multidisciplinary (Strijbos \& Fischer, 2007), it has frequently been applied in language learning contexts. Slavin (2011) conceptualizes collaborative learning as an instructional procedure whereby students of all levels of performance work together in small groups to achieve a group goal. Previously, Lv (2014) added that collaborative learning is a systematic teaching strategy that makes learners cooperate in a heterogenous team to achieve a common goal. Deducing from the definitions, the outcome of collaborative learning should reflect development as a goal is achieved. The study operationalizes the achievement of a common goal as improving the writing skills of learners. This is achieved through group (social) interaction.

In trying to devise an approach to collaborative learning, Hunter (1999) explains five impacts of collaborative learning. First, it engages students as active learners; second, it enriches students' learning experience; third, it creates an interactive context for learning; fourth, it encourages discussions and questioning; fifth, it develops the skills of learners. Bower and Richards (2006) have recognised collaborative learning to enhance deep learning and facilitate problem-solving. However, Kuusisaari (2013) admonishes that in the effort of adopting collaborative learning for language learning, it should not shift its focus from the objectives of teaching. That is, collaborative learning in improving the writing skills of learners should be tailored with the objectives of teaching writing.

Based on the SCT, collaborative learning supports students to improve their writing skills. Collaboration learning provides prospects for a conversational classroom (Bower \& Richards, 2006). Chandra (2015) points out that collaborative learning celebrates diversity as Lv (2014) and Umar et al. (2020) term it as heterogeneity. Also, there is interpersonal development and opportunities for feedback from peers. According to McLeod and Soven (1992), collaborative learning holds at its core that writing is a social process rather than individual effort which reflects the essence of the SCT in learning writing.

\section{Previous Studies}

Several studies have shown the applicability of collaborative learning (Ibrahim et al., 2020; Umar et al., 2020; van Leeuwen \& Janssen, 2019; Zhang \& Cui, 2018) in ESL learning contexts. Existing kinds of literature in ESL contexts have not overlooked investigating writing skills as well (Azlan \& Yunus, 2020; Bonsu, 2021; Elboshi, 2021; Khazrouni, 2018).

Veramuthu and Shah's (2020) study reviewed how effective collaborative learning is among secondary school students in an ESL classroom. Their study reviewed the importance of collaborative learning and was mainly guided by one research aim; to investigate the perceptions of ESL students towards collaborative writing. The study used a quantitative approach and data was collected through the questionnaire guide. After analysing data from 32 students, they finalize that collaborative learning as an approach to writing is helpful to students. The students showed positive perceptions towards collaborative learning to writing. This informs language education tutors in their instructional designs. 
Umar et al. (2020) analysed the impact of collaborative learning on language skill achievement in the ESL classroom. Quite differently, Umar et al. adopted an experimental design where pre-tests and post-tests were carried out with 44 students. They focused on all the language skills (reading, speaking, listening and writing). They report that collaborative learning enhances the achievement of students in learning English. As such, there is a positive relationship between collaborative learning and language skill development. Similar finding has been reported by Galarza Pucha (2020) who identified a statistically significant difference between post-test and pre-tests confirming a positive relationship between collaborative learning and writing. A collaborative learning environment enhances the essay writing of students.

On writing, Chokwe (2013) reviewed the factors that impact the writing skills of students in ESL contexts. While there were external factors to the educational context (such as colonialism), the most enticing mention was the underprepared teachers and ineffective teaching approaches to writing. This does not allow students to be actively engaged in the process of learning writing. Chokwe argues for effective measures to address poor writing skills. To this call, Ibrahim et al. (2015) presented the relevance of incorporating collaborative writing in the ESL classroom. Through collaborative learning, students provide support for one another and improve their writing skills (Galarza Pucha, 2020). Shull (2001) examined the effectiveness of collaborative learning that used peer feedback to improve writing skills. This study was fundamentally aimed at descrying whether collaborative learning could solve the problems of writing skills. Shull reported an improvement in the writing of the students in the experimental group as compared to the control group. The essence of peer feedback in language education has been acknowledged by Tian and Zhou (2020), Lin (2018) and Gaynor (2020). These studies have essentialized the importance of peer support in improving learning and writing. Elboshi's (2021) empirical review reports significant improvement in the writing skills of students through peer support. Azlan and Yunus (2020) sought to incorporate the growing demand for social networking sites from undergraduates and how it affects their writing. The students perceived their writing to have improved through such sites. This is not out of context as such sites are envisaged as a social community where peers interact and share knowledge.

From the review of previous studies, it can be affirmed that the studies used SPSS as a quantitative tool for analysis. The use of a quantitative approach and a questionnaire instrument was evidenced as well. These methodological grounds justify the need for the study to adopt the same. Also, the impact of collaborative learning on language learning generally and writing specifically has been reported through the studies. Most importantly, the relevance of peers in the process of improving the writing skills of others has been influential in the literature.

\section{Materials And Methods}

The participants for the study were drawn from Level 300 English Major students from the Department of English. The selected participants for the study were 30 students. The number of participants is justified based on the review of previous studies where the number ranged between 20 to 55 . The participants 
were randomly sampled from a single class of sixty-five (65) students. This procedure was adopted because each of the students has engaged in collaborative learning from the onset of their university education. From personal observations, such collaborative learnings have been geared towards sharing knowledge and building writing strategies for their examinations. Therefore, the participants offered suitable responses for the study.

The study uses a descriptive survey design. According to Nassaji (2015), descriptive design describes the characteristics of a phenomenon or subjects in a study. The descriptive survey design aims to collect, analyse and interpret data from respondents. The design is to evaluate the perceptions towards the practice of collaborative learning. As this study mainly draws on behavioural investigations, the descriptive survey is suitable for this study. Additionally, the quantitative research approach is adopted to analyse the data. The quantitative research approach was adopted because it offers multifaceted means to analyse the data statistically.

Given the design and approach of the study, the questionnaire instrument was used for the data collection. Understandably, the design, approach, and instrument ensure the credibility of the results. The questionnaire instrument is widely used in second language research for the past two decades (Dornyei \& Taguchi, 2009; Seker \& Dincer, 2014). This tool was adopted based on its efficiency, less expensiveness, and wide coverage of participants. As such, it is hoped that the findings of this study demonstrate the perceptions of ESL students towards collaborative learning improving their writing skills. The questionnaire comprised two main sections (Section A and Section B).

The data obtained were analysed with Statistical Package for Social Sciences version 25 (SPSS 25). This statistical analysis tool has proven to be effective in quantitative research. The tool was used to descriptive statistics to provide a summary of the analysis in the form of means, frequencies, tables, and standard deviation. The direction of the analysis of the data was used to determine the perceptions and effect of collaborative learning on improving the writing skills of ESL students.

\section{Results}

The results of the data collected and analysed from the participants are presented in Tables 1 and 2 . Table 1 presents the results of the analysis for the research question (i) while Table 2 presents the analysis for the research question (ii). The results are presented in percentages, frequencies, means and standard deviation. In the two tables, the keys are explained as SD = Strongly Disagree, $D=$ Disagree, $U n=$ Uncertain, $A=$ Agree, $S A=$ Strongly Agree,$M=$ Mean, and StD = Standard Deviation . 
Table 1

Perceptions of Students towards Collaborative Learning

\begin{tabular}{|c|c|c|c|c|c|c|c|}
\hline \multirow[t]{2}{*}{ Statements } & $S D$ & D & Un & A & SA & $M$ & StD \\
\hline & $F(\%)$ & $F(\%)$ & $F(\%)$ & $F(\%)$ & $F(\%)$ & & \\
\hline $\begin{array}{l}\text { 1. I do not like to work or learn with } \\
\text { my friends. }\end{array}$ & $\begin{array}{l}11 \\
(36.7)\end{array}$ & $6(20)$ & $\begin{array}{l}7 \\
(23.3)\end{array}$ & $6(20)$ & - & 2.27 & 1.172 \\
\hline $\begin{array}{l}\text { 2. Collaborative learning helps us to } \\
\text { share knowledge and build } \\
\text { experience. }\end{array}$ & $\begin{array}{l}2 \\
(6.7)\end{array}$ & $\begin{array}{l}2 \\
(6.7)\end{array}$ & $6(20)$ & $\begin{array}{l}11 \\
(36.7)\end{array}$ & $9(30)$ & 3.77 & 1.165 \\
\hline $\begin{array}{l}\text { 3. Collaborative learning helps me to } \\
\text { improve my language skills. }\end{array}$ & $\begin{array}{l}1 \\
(3.3)\end{array}$ & $\begin{array}{l}4 \\
(13.3)\end{array}$ & $3(10)$ & $\begin{array}{l}8 \\
(26.7)\end{array}$ & $\begin{array}{l}14 \\
(46.7)\end{array}$ & 4.00 & 1.203 \\
\hline $\begin{array}{l}\text { 4. I am more active during } \\
\text { collaborative learning. }\end{array}$ & $\begin{array}{l}1 \\
(3.3)\end{array}$ & $\begin{array}{l}2 \\
(6.7)\end{array}$ & $\begin{array}{l}3 \\
(10.0)\end{array}$ & $\begin{array}{l}14 \\
(46.7)\end{array}$ & $\begin{array}{l}10 \\
(33.3)\end{array}$ & 4.00 & 1.017 \\
\hline $\begin{array}{l}\text { 5. Collaborative learning enhances } \\
\text { my social skills. }\end{array}$ & $\begin{array}{l}4 \\
(13.3)\end{array}$ & $\begin{array}{l}4 \\
(13.3)\end{array}$ & $\begin{array}{l}5 \\
(16.7)\end{array}$ & $\begin{array}{l}10 \\
(33.3)\end{array}$ & $\begin{array}{l}7 \\
(23.3)\end{array}$ & 3.40 & 1.354 \\
\hline
\end{tabular}

Table 1 presents the results of the analysis on the data collected to determine the perceptions of students towards collaborative learning. From the results, $36.7 \%$ of the students indicated that they 'strongly disagree' with the statement that 'I do not like to work or learn with my friends'. While $23.3 \%$ were 'Uncertain', there was a percentage tie score for 'Disagree' and 'Agree' at 6\% each. The mean of the item was 2.27 with a standard deviation of 1.172 indicating a high measure of spread. Given the mean of 2.27 , it can be determined that the students have a positive perception about learning with their peers which are expressed through their disagreement with the negative statement. On item 2 of the questionnaire, the students expressed that collaborative learning helps them to share knowledge and build experience through an agreement of $66.7 \%$ (i.e., $A\{36.7\}+\mathrm{SA}\{30\}$ ). The disagreement with the statement was at $13.4 \%$ while $20 \%$ were uncertain. Although the measure of spread is high, the mean score of 3.77 indicates the students' positive perceptions about collaborative learning helping them increase their knowledge. The mean is skewed to 4 which reflects the certainty that comes with the 'agreement' to the statement. The language skills development through collaborative learning was also included. To that, $26.7 \%$ of the students 'agreed' and $46.7 \%$ 'strongly agreed'. $16.6 \%$ (i.e., SD $\{3.3\}+D$ $\{13.3\})$ of the students expressed disagreement. Their language skills were not improved through the collaborative learning activities. $10 \%$ were uncertain about the improvement in language skills. Given a standard deviation of 1.203 and a mean of exactly 4.00 , more than $66 \%$ of the 'agreement' falls within the standard deviation which confirms the improvement of language skills of learners through collaborative learning. From item 4, the least standard deviation (1.017) was recorded in line with a mean of 4.00 . Compared to the other responses, the variation, though above 1 , is relatively low. $80 \%$ (i.e., SA $\{33.3\}+$ A $\{46.7\})$ of the students 'agreed' that they are active in collaborative learning activities. The disagreement was hinged at a percentage of 10 (i.e., SD $\{3.3\}+D\{6.7\}$ ) and $10 \%$ was also uncertain. From the results, it 
is confirmed that students are more active during collaborative learning. Finally, the last item on the questionnaire sought to find out the enhancement in the social skills of students through collaborative learning. $13.3 \%$ of the students 'strongly disagree' that collaborative learning enhances their social skills, $13.3 \%$ 'agreed', and $16.7 \%$ showed uncertainty. $33.3 \%$ 'agreed' and $23.3 \%$ 'strongly agreed' that their social skills were developed. This statement attracted the highest standard deviation of 1.354 with a mean of 3.40. The mean is within the range of 'Uncertain'. From the variation in the spread of responses, the results show that the students are unsure how their social skills are enhanced through collaborative learning.

Table 2

Perceived Effects of Collaborative Learning on Writing Skills

\begin{tabular}{|c|c|c|c|c|c|c|c|}
\hline \multirow[t]{2}{*}{ Statements } & SD & D & Un & A & SA & \multirow[t]{2}{*}{$M$} & \multirow[t]{2}{*}{ StD } \\
\hline & $F(\%)$ & $F(\%)$ & $\mathrm{F}(\%)$ & F (\%) & $F(\%)$ & & \\
\hline $\begin{array}{l}\text { 1. Writing together in groups is a } \\
\text { strategy that helps me to write clearly. }\end{array}$ & $\begin{array}{l}1 \\
(3.3)\end{array}$ & - & $\begin{array}{l}8 \\
(26.7)\end{array}$ & $\begin{array}{l}12 \\
(40)\end{array}$ & $9(30)$ & 3.93 & .944 \\
\hline $\begin{array}{l}\text { 2. Planning and outlining a topic with } \\
\text { my friends help me more than I do } \\
\text { alone. }\end{array}$ & $\begin{array}{l}1 \\
(3.3)\end{array}$ & $\begin{array}{l}2 \\
(6.7)\end{array}$ & $\begin{array}{l}5 \\
(16.7)\end{array}$ & $\begin{array}{l}14 \\
(46.7)\end{array}$ & $\begin{array}{l}8 \\
(26.7)\end{array}$ & 3.87 & 1.008 \\
\hline $\begin{array}{l}\text { 3. Developing my own writing is not } \\
\text { helpful for me. }\end{array}$ & $\begin{array}{l}2 \\
(6.7)\end{array}$ & $\begin{array}{l}4 \\
(13.3)\end{array}$ & $3(10)$ & $\begin{array}{l}7 \\
(23.3)\end{array}$ & $\begin{array}{l}14 \\
(46.7)\end{array}$ & 3.90 & 1.322 \\
\hline $\begin{array}{l}\text { 4. Peers in my group provide good } \\
\text { comments on my writing. }\end{array}$ & $\begin{array}{l}1 \\
(3.3)\end{array}$ & $\begin{array}{l}2 \\
(6.7)\end{array}$ & $6(20)$ & $\begin{array}{l}10 \\
(33.3)\end{array}$ & $\begin{array}{l}11 \\
(36.7)\end{array}$ & 3.93 & 1.081 \\
\hline $\begin{array}{l}\text { 5. I cannot edit or proofread my own } \\
\text { writing alone. }\end{array}$ & $3(10)$ & $\begin{array}{l}8 \\
(26.7)\end{array}$ & $6(20)$ & $\begin{array}{l}7 \\
(23.3)\end{array}$ & $6(20)$ & 3.17 & 1.315 \\
\hline $\begin{array}{l}\text { 6. I do not prefer feedback from my } \\
\text { peers on my writing. }\end{array}$ & $\begin{array}{l}11 \\
(36.7)\end{array}$ & $\begin{array}{l}12 \\
(40)\end{array}$ & $\begin{array}{l}5 \\
(16.7)\end{array}$ & $\begin{array}{l}2 \\
(6.7)\end{array}$ & - & 1.93 & .907 \\
\hline $\begin{array}{l}\text { 7. I would like to engage in more } \\
\text { collaborative writing activities. }\end{array}$ & $\begin{array}{l}2 \\
(6.7)\end{array}$ & $\begin{array}{l}1 \\
(3.3)\end{array}$ & $\begin{array}{l}2 \\
(6.7)\end{array}$ & $\begin{array}{l}12 \\
(40)\end{array}$ & $\begin{array}{l}13 \\
(43.3)\end{array}$ & 4.10 & 1.125 \\
\hline $\begin{array}{l}\text { 8. Collaborative learning helps me } \\
\text { acquire new vocabularies to use in } \\
\text { my writing. }\end{array}$ & - & $\begin{array}{l}4 \\
(13.3)\end{array}$ & $3(10)$ & $\begin{array}{l}11 \\
(36.7)\end{array}$ & $\begin{array}{l}12 \\
(40)\end{array}$ & 4.03 & 1.033 \\
\hline $\begin{array}{l}\text { 9. My writing skill was better before I } \\
\text { engaged in collaborative learning. }\end{array}$ & $9(30)$ & $9(30)$ & $3(10)$ & $\begin{array}{l}7 \\
(23.3)\end{array}$ & $\begin{array}{l}2 \\
(6.7)\end{array}$ & 2.47 & 1.332 \\
\hline $\begin{array}{l}\text { 10. Overall, I think collaborative } \\
\text { learning has positive effects on my } \\
\text { writing skill. }\end{array}$ & $\begin{array}{l}2 \\
(6.7)\end{array}$ & $\begin{array}{l}1 \\
(3.3)\end{array}$ & $6(20)$ & $\begin{array}{l}7 \\
(23.3)\end{array}$ & $\begin{array}{l}14 \\
(46.7)\end{array}$ & 4.00 & 1.203 \\
\hline Source: Field data, 2021 & & & & & & & \\
\hline
\end{tabular}

Table 2 provides the results for the analysis of the perceived effects of collaborative learning on writing skills. From Table 2 on item 1, 70\% (i.e., SA $\{30\}+A\{40\}$ ) of the students ascertained the effect that 
collaborative learning has on the clarity of their writing. The mean score of 3.93 indicates an agreement was attained. The standard deviation was low and appreciable, given that the data is clustered around the mean. This points out that collaborative writing improves the clarity of writing of students. Planning and outlining are important to writing. With a percentage of 73.4 (i.e., SA $\{26.7\}+A\{46.7\}$ ), the students expressed a total agreement that planning and outlining a topic for writing with their peers are useful for them. A standard deviation of 1.008 and a mean of 3.87 was attained. The scores determine that collaborative learning impacts the planning and outlining of students. On item 3 , there was a high spread out of data with a standard deviation of 1.322 from the mean of 3.90 . Nonetheless, $70 \%$ (i.e., SA $\{23.7\}+$ A \{46.7\}) of the students agreed that developing their own writing is not helpful for them. That is, they require assistance from their peers to develop better writing. The skewness of the mean score towards 4.00 establishes that students need support from peers to develop their writing plan. Additionally, on the provision of good comments from peers, $36.7 \%$ of the students 'strongly agreed' and $33.3 \%$ 'agreed' to the statement. Given a mean of 3.93 and a standard deviation of 1.081, the results confirm that peers provide good comments which positively affects writing skills. Item 5 sought to identify the possible capacity of students to edit and proofread their writing. $26.7 \%$ representing the majority 'disagreed' and $10 \%$ 'strongly disagreed' with the statement. This shows that the students do not require to be in groups in order to edit their writing. $23.3 \%$ 'agreed' and $20 \%$ 'strongly agreed' indicating their inability to edit their writing. $20 \%$ were 'uncertain' about the statement. Attaining a mean score of 3.17, it is confirmed that students are not sure as to whether they can proofread their writings alone or not.

While the students disagreed (76.7\%) with the statement that 'I do not prefer feedback from my peers on my writing' (Item 6), the students confirmed the positive effect peer feedback has on their writing. The mean score was 1.93 with the least standard deviation of .907. This response is appreciable because the students indicated the 'good comments' they get from their peers in item 4. That is, the good comments motivate the students to prefer feedback from peers. The highest mean score of 4.10 was attained for item 7. The students expressed their interest in engaging in frequent collaborative writing activities. This is supported with an $83.3 \%$ agreement (i.e., SA $\{43.3\}+A\{40\}$ ). Vocabulary development is essential to improving writing. To this, $76.7 \%$ (i.e., SA $\{40\}+A\{36.7\}$ ) of the students agreed that they acquire new vocabularies through collaborative learning. Though the responses were spread out (standard deviation = 1.033), the mean score (4.03) confirms the level of agreement to item 8 . For item $9,60 \%$ (i.e., SD $\{30\}+D$ $\{30\})$ of the students disagreed that their writing was better before collaborative learning activities. This implies that the writing skills of the students improved through collaborative learning and not prior to it. With a 2.47 mean, it is evident that collaborative learning betters the writing of learners. Finally, item 10 sought ground to confirm the positive effect collaborative learning has on writing skills. With a $70 \%$ agreement (i.e., $A\{23.7\}+S A\{46.7\}$ ) and a mean of 4.00 , the students expressed that collaborative learning has a positive effect on their writing skills.

\section{Discussion}

The perception or understanding of students can be a motivational factor to their engagement in collaborative learning. The students demonstrated through their responses that they have a positive 
perception of collaborative learning. This finding is supported by the studies of Veramuthu and Shah (2020) who also confirm the positive perception of students towards collaborative learning. Given this positive perception, the participants also confirmed that they would like to engage in more collaborative learning activities. This expression of interest is facilitated by the positive perceptions of the students. As such, they become more active during the collaborative learning process. These findings are inherent in the thrust of the SCT where active engagement improves learning. This is consistent with the report by Hunter (1999) and Lv (2014) where learners are active participants and take charge of their learning in collaborative activities.

Consistent with the findings of other studies, the study reveals that students have a positive perception of collaborative learning since they can share knowledge and build experience. Bulut (2017) also added the positive perceptions of students towards collaborative learning. Also, it is affirmed that the general language skills of learners are developed through collaborative learning. These findings are supported by Umar et al. (2020) who confirmed a positive relationship between collaborative learning and language skills development. Previously, Laal and Ghodsi (2012) added the active interaction in collaborative learning to improve the language skills of learning. On writing, it was found that there is an effect of collaborative learning on improving the clarity, planning, and outlining of writing. Rice and Huguley (1994) are amongst the researchers who have reported such positive effects of collaborative learning on clarity, planning, and outlining writing.

The study reports that students cannot develop their writing on their own. As such, the support of peers is required. In this regard, it was indicated that peer feedback is helpful to improve writing skills. The comments from peers were found to be useful in improving writing. These findings imply the significance of peer feedback comments on improving writing. The report of the current study is hinged on the scholarship on peer feedback from Bower and Richards (2006), Sukirman (2016) and Shull (2001). Peer feedback serves as a guide to others to foster and improve their writing skills (Elboshi, 2021). From the SCT, peer feedback creates an interactive learning context in a friendly manner (Bower \& Richards, 2006).

Collaborative learning is envisaged as a social learning process. Although Laal (2013) reported social skills to be elemental in collaborative learning, it was found that students have an indifferent concern about how collaborative learning improves their social skills. Here, the social skills comprise the establishment of interpersonal relations in the heterogeneous group. Additionally, no effect was realised on the ability of students to proofread and edit their work. The study formulates that this inability rises from the individual acts in trying to carry out the proofreading and editing task. This is concurring with Wilmar's (2008) claim that learners are unable to take on complex language learning tasks (where writing is a complex cognitive task) on their own.

As opined earlier, vocabularies are relevant to improving writing skills. In that regard, it was revealed that students acquire new vocabularies through collaborative learning. Similar findings are reported from the study of Lin, Hsiao, Tseng and Chan (2014). These vocabularies are used in the writing process which reflects the development of the students. In addition, the writing skills of the students improved through 
collaborative learning. Generally, the study reports a positive perceived effect of collaborative learning on improving the writing skills of the students. The final report from the present study is supported by the findings of Al-Besher (2012), Mansoor (2007), Sukirman (2016), Ibrahim et al. (2015) and Umar et al. (2020) who revealed the effect of collaborative learning on writing skills.

\section{Conclusion And Implication}

The study was conducted to evaluate the perceptions of ESL students towards collaborative learning on improving their writing skills in an English language classroom. While the findings of the study are credible, some limitations are provided concerning the study. First, the number of participants used though justified based on previous studies, is relatively small. This affects the deductive generalizability of the results of the study to the entire population or other ESL contexts. Second, there was no regression analysis to establish the relationship between collaborative learning and writing skills. Such methodological approaches were adopted by Galarza Pucha (2020) and Umar et al. (2020). Finally, the study did not further investigate the students' 'uncertain' perception about the development of social skills through collaborative learning. It is proposed that interview guides could have made up for this. Despite these limitations, the study reports a positive perception towards collaborative learning and a positive effect of collaborative learning on writing skills. In this regard, the study recommends that educationists should adopt collaborative learning as a core instructional strategy to foster language skills development in the classroom and other learning contexts. Given the great importance placed on peer feedback in writing, writing curricula and other textbooks developers should incorporate activities where peers could interact and improve their writing as they benefit from one another's writing. From the limitations identified, further research can investigate the relationship between collaborative learning and writing adopting a mixed-method approach. The participants in such a study can be increased in order to provide wider generalizability. Finally, further studies can compare the development of social skills through collaborative learning on online platforms and classroom contexts.

\section{Declarations}

\section{Conflict of Interest}

There are no conflict of interests.

Consent: The participants involved in the study gave their consent to participate in the study and also for for the publication as well.

\section{References}

1. AbuSeileek, A., \& Abualsha'r, A. (2014). Using peer computer-mediated corrective feedback to support EFL learners' writing. Language Learning \& Technology, 18(1), 76-95. 
2. Afful, J. B. A. (2007). Academic literacy and communicative skills in the Ghanaian university: A proposal. Nebula, 4(3), 141-161.

3. Al-Besher, K. (2012). Developing the writing skills of ESL students through the collaborative learning strategy (Doctoral dissertation, Newcastle University).

4. Alghasab, M., Hardman, J., \& Handley, Z. (2019). Teacher-student interaction on wikis: Fostering collaborative learning and writing. Learning, Culture and Social Interaction, 21, 10-20.

5. Arancón, P. R. (2013). The use of SFL genre theory for the analysis of students' writing skills in ESP. Revista Española de Lingüística Aplicada, 2(1), 245-262.

6. Atkinson, D. (2019). Beyond the brain: Intercorporeality and co-operative action for SLA studies. The Modern Language Journal, 103(4), 724-738.

7. Azlan, N. A. B., \& Yunus, M. M. (2020). Undergraduate students' perceptions of social networking sites to improve English writing skills in Malaysia. International Journal of Learning, Teaching and Educational Research, 19(3), 329-351.

8. Barnard, R., \& Compbell, L. (2005). Sociocultural theory and the teaching of process writing: the scaffolding of learning in a university context. The TESOLANZ Journal, 13, 76-88.

9. Barrot, J. (2015). A sociocognitive-transformative approach to teaching writing. Indonesian Journal of Applied Linguistics, 4(2), 113-122.

10. Bonsu, E. (2021). The influence of written feedback on the writing skill performance of high school students. International Journal of Applied Research in Social Sciences, 3(3), 33-43.

11. Bower, M., \& Richards, D. (2006). Collaborative learning: Some possibilities and limitations for students and teachers. Australasian Society for Computers in Learning in Tertiary Education 23rd Conference, 3-6. Australia: Sydney.

12. Bowles, M. A., \& Adams, R. J. (2015). An interactionist approach to learner-learner interaction in second and foreign language classrooms. The handbook of classroom discourse and interaction, 198-212.

13. Bulut, P. (2017). The effect of primary school students' writing attitudes and writing self-efficacy beliefs on their summary writing achievement. International Electronic Journal of Elementary Education, 10(2), 281-285.

14. Chandra, R. (2015). Collaborative learning for educational achievement. IOSR Journal of Research \& Method in Education, 5(2), 78-85.

15. Chokwe, J. M. (2013). Factors impacting academic writing skills of English second language students. Mediterranean Journal of Social Sciences, 4(14), 377-384.

16. Dongyu, Z., Fanyu, B., \& Wanyi, D. (2013). Sociocultural theory applied to second language learning: Collaborative learning with reference to the Chinese context. International Education Studies, 6(9), 165-174.

17. Dörnyei, Z., \& Taguchi, T. (2009). Questionnaires in second language research: Construction, administration, and processing. London: Routledge. 
18. Elboshi, A. (2021). Web-Enhanced Peer Feedback in ESL Writing Classrooms a Literature Review. English Language Teaching, 14(4), 66-76.

19. Fan, Y., \& Xu, J. (2020). Exploring student engagement with peer feedback on L2 writing. Journal of Second Language Writing, 50, 10-26.

20. Farrah, M. (2011). Attitudes towards collaborative writing among English majors in Hebron University. Arab World English Journal, 2, 136-170.

21. Flower, L., \& Hayes, J. (1981). A cognitive process theory of writing. College Composition and Communication, 32, 365-387.

22. Flower, L., \& Hayes, J. R. (1981). A cognitive process theory of writing. College Composition and Communication, 32(4), 365-387.

23. Gaynor, J. W. (2020). Peer review in the classroom: student perceptions, peer feedback quality and the role of assessment. Assessment \& Evaluation in Higher Education, 45(5), 758-775.

24. Gredler, M. E. (1997). Learning and instruction: Theory into practice (3rd ed.). Upper Saddle River, NJ: Prentice-Hall.

25. Hayes, J., \& Flower, L. (1987). On the structure of the writing process. Topics in Language Disorder, 7 (4), 19-30.

26. Hodson, D., \& Hodson, J. (1998). From constructivism to social constructivism: A Vygotskian perspective on teaching and learning science. School science review, 79(289), 33-41.

27. Huisman, B., Saab, N., Van Driel, J., \& Van Den Broek, P. (2018). Peer feedback on academic writing: undergraduate students' peer feedback role, peer feedback perceptions and essay performance. Assessment \& Evaluation in Higher Education, 43(6), 955-968.

28. Hunter, D. (1999). Developing peer-learning programmes in music: Group presentations and peer assessment. British Journal of Music Education, 16(1), 51-63.

29. Huy, N. T. (2015). Problems affecting learning writing skill of grade 11 at Thong Linh high school. Asian Journal of Educational Research, 3(2), 34-51.

30. Hyland, K., \& Hyland, F. (Eds.). (2019). Feedback in second language writing: Contexts and issues. Cambridge: Cambridge University Press.

31. Ibrahim, N., Shak, M. S. Y., Mohd, T., Zaidi, A., \& Yasin, S. M. A. (2015). The importance of implementing collaborative learning in the English as a second language (ESL) classroom in Malaysia. Procedia Economics and Finance, 31, 346-353.

32. Ivanič, R. (1998). Writing and identity (Vol. 10). Amsterdam: John Benjamins.

33. Kafai, Y., \& Resnick, M. (1996). Constructionism in practice: Designing, thinking, and learning in a digital world. Mahwah, NJ: Lawrence Erlbaum Associates.

34. Khan, A. B., \& Mansoor, H. S. (2020). Integrated Collaborative Learning Approach (ICLA): Conceptual framework of pedagogical approach for the integration of language skills. Competitive Social Science Research Journal, 1(1), 14-28. 
35. Khazrouni, M. (2019). Assessment for improving ESL learners' writing skills among undergraduate students: A case study of Skyline University College. International Journal of English Language Teaching, $7(1), 30-44$.

36. Kheryadi, K. (2017). Improving students' writing narrative through writing games for acceleration class. EduLite: Journal of English Education, Literature and Culture, 2(2), 377-388.

37. Kohonen, V., \& Bedley, G. (1992). Experiential language learning: Second language learning as cooperative learner education. Collaborative Language Learning and Teaching, 45-64.

38. Kukla, A. (2000). Social Constructivism and the Philosophy of Science. New York: Routledge.

39. Kuusisaari, H. (2013). Teachers' collaborative learning-development of teaching in group discussions. Teachers and Teaching, 19(1), 50-62.

40. Laal, M. (2013). Collaborative learning; elements. Procedia-Social and Behavioral Sciences, 83, 814818.

41. Laal, M., \& Ghodsi, S. M. (2012). Benefits of collaborative learning. Procedia - Social and Behavioural Sciences, 31, 486-490.

42. Lantolf, J. P. (Ed.) (2000). Sociocultural theory and second language learning: Recent advances. Oxford, England: Oxford University Press.

43. Lin, C. C., Hsiao, H. S., Tseng, S. P., \& Chan, H. J. (2014). Learning English vocabulary collaboratively in a technology-supported classroom. Turkish Online Journal of Educational Technology-TOJET, 13(1), 162-173.

44. Lin, G. Y. (2018). Anonymous versus identified peer assessment via a Facebook-based learning application: Effects on quality of peer feedback, perceived learning, perceived fairness, and attitude toward the system. Computers \& Education, 116, 81-92.

45. Lv, Y. (2014). Cooperative learning: An effective approach to college English learning. Theory \& Practice in Language Studies, 4(9), 1-14.

46. Mansor, N. (2007). Collaborative learning via email discussion: Strategies for ESL writing classroom. The Internet TESL Journal, 13(3), 11-24.

47. Mazhar, B. A. L. (2019). Use of digital games in writing education: An action research on gamification. Contemporary Educational Technology, 10(3), 246-271.

48. McLeod, S. H., \& Soven, M. (1992). Writing across the curriculum. Writing across the curriculum: A guide to developing programs, 77, 1-20.

49. Nassaji, H. (2015). Qualitative and descriptive research: Data type versus data analysis. Language Teaching Research, 19(2), 129-132.

50. Pea, R. D. (1993). Practices of distributed intelligence and designs for education. In G. Salomon (Ed.), Distributed cognitions: Psychological and educational considerations (pp. 47-87). New York: Cambridge University Press.

51. Pham, V. P. H., \& Nguyen, N. H. V. (2020). Blogging for Collaborative Learning in the Writing Classroom: A Case Study. International Journal of Cyber Behavior, Psychology and Learning 
(IJCBPL), 10(3), 1-11.

52. Qing-quan, N. I. (2009). The Development of Student Writing Ability via Collaborative-Learning-Based Writing in a Computer/Web Environment [J]. Computer-Assisted Foreign Language Education in China, 3, 1-12.

53. Rice, R. P., \& Huguley, J. T. (1994). Describing collaborative forms: A profile of the team-writing process. IEEE Transactions on Professional Communication, 37(3), 163-170.

54. Sauro, S. (2009). Computer-mediated corrective feedback and the development of L2 grammar. Language Learning \& Technology, 13(1), 96-120.

55. Schuldt, L. C. (2019). Feedback in action: Examining teachers' oral feedback to elementary writers. Teaching and Teacher Education, 83, 64-76.

56. Seker, M., \& Dincer, A. (2014). an insight to students' perceptions on teacher feedback in second language writing classes. English Language Teaching, 7(2), 73-83.

57. Slavin, R. E. (2011). Cooperative learning. Learning and cognition in education, 160-166.

58. Solhi, M., \& Eğinli, İ. (2020). The Effect of recorded oral feedback on EFL learners' writing. Journal of Language and Linguistic Studies, 16(1), 1-13.

59. Srour, K., Aqel, M., \& Shawish, J. I. (2021). Enhancing EFL secondary school students' writing skills through a suggested model based on constructivism. Education in the knowledge society: EKS, 22, $10-13$.

60. Strijbos, J. W., \& Fischer, F. (2007). Methodological challenges for collaborative learning research. Learning and Instruction, 17(4), 389-393.

61. Sukirman, S. (2016). Using collaborative writing in teaching writing. Langkawi: Journal of The Association for Arabic and English, 2(1), 33-46.

62. Tian, L., \& Zhou, Y. (2020). Learner engagement with automated feedback, peer feedback and teacher feedback in an online EFL writing context. System, 91, 22-47.

63. Umar, A. M. A. T., Adamm, A. A., \& Fahal, A. A. (2020). Impact of Cooperative Learning on achievement in an English as a Second Language classroom. International Journal of English and Education, 9(3), 1-15.

64. Van Boxtel, C., Van der Linden, J., \& Kanselaar, G. (2000). Collaborative learning tasks and the elaboration of conceptual knowledge. Learning and Instruction, 10(4), 311-330.

65. van Leeuwen, A., \& Janssen, J. (2019). A systematic review of teacher guidance during collaborative learning in primary and secondary education. Educational Research Review, 27, 71-89.

66. Van Lier, L (2000). From input to affordance: Social-interactive learning from an ecological perspective. In J.P. Lantolf (Ed.) (2000) Sociocultural theory and second language learning: Recent advances (pp. 245-259). Oxford, England: Oxford University Press.

67. Veramuthu, P., \& Shah, P. M. (2020). Effectiveness of collaborative writing among secondary school students in an ESL classroom. Creative Education, 11(1), 54-67. 
68. Vygotsky, L. (1978). Interaction between learning and development. Readings on the development of children, 23(3), 34-41.

69. Warmkessel, M. M., \& Carothers, F. M. (1993). Collaborative learning and bibliographic instruction. The Journal of Academic Librarianship, 19(1), 4-7.

70. Weigle, S. C. (2007). Teaching writing teachers about assessment. Journal of Second Language Writing, 16(3), 194-209.

71. Wilmer, E. (2008). Student support services for the underprepared student. Inquiry, 13(1), 5-19.

72. Zhang, J., \& Cui, Q. (2018). Collaborative learning in higher nursing education: A systematic review. Journal of Professional Nursing, 34(5), 378-388. 